\title{
PENGARUH KONSEP 5C TERHADAP KEPUTUSAN PEMBERIAN KREDIT PADA UNIT USAHA SIMPAN PINJAM KUD KARYA MUKTI KUAMANG KUNING MUARA BUNGO
}

\author{
Sukma Dewi Anggraini'; ${ }^{1}$ Ira Widyastuti² \\ Sekolah Tinggi Ilmu Administrasi Setih Setio Muara Bungo \\ Email korespondensi: sukmadewi1919@gmail.com ${ }^{1}$
}

Received: 3 Sept 2020 Reviewed: 9 Sept 2020 Accepted: 12 Oct $2020 \quad$ Published:30 Oct 2020

\begin{abstract}
The purpose of this study was to determine the effect of the 5C concept on the loan decision at the KUD Karya Mukti Kuamang Kuning Savings and Loan Business Unit. The population in this study were all members of the KUD Karya Mukti Village as many as 1,522 people. Meanwhile, the sample in this study was determined by the Slovin formula with a significant $\alpha$ of $10 \%$ (0.1) as many as 94 respondents. The analysis used is multiple linear regression analysis with the help of the SPSS program version 20. The results of this study indicate that simultaneously the 5C concept has a significant effect on the loan decision on KUD Karya Mukti Savings and Loan Business Unit in Kuamang Kuning. The partial test results show that the character variable has a significant effect on loan decision, variable capacity has no significant effect on loan decision, variable capital has no significant effect on loan decision with, the collateral variable has a significant effect on the decision to give credit, the variable condition of economy has a significant effect on loan decision.
\end{abstract}

Keywords: 5 C Concepts, Loan Decision, Koperasi Unit Desa

\begin{abstract}
ABSTRAK
Tujuan penelitian ini adalah untuk mengetahui pengaruh antara pengaruh konsep 5C terhadap keputusan pemberian kredit pada Unit Usaha Simpan Pinjam KUD Karya Mukti di Kuamang Kuning. Populasinya adalah seluruh anggota Koperasi Unit Desa Karya Mukti sebanyak 1522 anggota. Sementara itu, sampel dalam penelitian ini ditetapkan dengan rumus Slovin dengan signifikan $\alpha 10 \%(0,1)$ sebanyak 94 responden. Analisis yang digunakan adalah analisis regresi linier berganda dengan bantuan program SPSS versi 20. Hasil dari penelitian ini menunjukkan bahwa secara simultan konsep 5C berpengaruh signifikan terhadap keputusan pemberian kredit pada Unit Usaha Simpan Pinjam KUD Karya Mukti di Kuamang Kuning. Hasil uji secara parsial menunjukkan bahwa variabel character berpengaruh signifikan terhadap keputusan pemberian kredit, variabel capaciy tidak berpengaruh signifikan terhadap keputusan pemberian kredit, variabel capital tidak berpengarh signifikan terhadap keputusan pemberian kredit, variabel collateral berpengaruh signifikan terhadap keputusan pemberian kredit, variabel condition of economy berpengaruh signifikan terhadap keputusan pemberian kredit.
\end{abstract}

Kata kunci: Konsep 5C, Keputusan Pemberian Kredit, Koperasi Unit Desa 


\section{A. PENDAHULUAN}

Abad modern ini uang memainkan peranan yang sangat penting dalam semua aktivitas masyarakat. Uang sudah menjadi kebutuhan pokok bagi masyarakat. Untuk itu di dalam memenuhi kebutuhan akan keuangan masyarakat cenderung bekerja maupun meminta bantuan kepada teman dekat, keluarga serta melakukan pinjaman kepada lembaga - lembaga yang menyediakan pinjaman seperti lembaga keuangan bank maupun lembaga keuangan bukan bank.

Koperasi simpan pinjam merupakan salah satu lembaga keuangan bukan bank. Kegiatan koperasi simpan pinjam memungut sejumlah uang dari anggota koperasi. Dalam pasal 19 Peraturan Pemerintah Nomor 9 Tahun 1995 ayat (2) menjelaskan bahwa dalam memberikan pinjaman, koperasi simpan pinjam dan unit simpan pinjam wajib memegang teguh prinsip pemberian pinjaman yang sehat dengan memperhatikan penilaian kelayakan dan kemampuan pemohon pinjaman, prinsip tersebut dikenal dengan istilah 5C yaitu character, capacity, capital, colleteral dan condition of economy.

Koperasi Unit Desa (KUD) Karya Mukti yang terletak di Dusun Karya Harapan Mukti, Kuamang Kuning Kabupaten Bungo memiliki beberapa unit usaha salah satunya yaitu unit usaha simpan pinjam. Berdasarkan data yang didapat dari pengurus USP beberapa tahun terakhir dalam penyaluran pinjaman mengalami persentase tunggakan yang cukup tinggi seperti terlihat pada tabel 1 .

Tabel 1. Data Kredit Pada KUD Karya Mukti di Kuamang Kuning

Tahun 2017 - Oktober 2019

\begin{tabular}{|c|c|c|c|c|c|c|}
\hline \multirow{2}{*}{ Th } & \multirow{2}{*}{$\begin{array}{c}\text { Total } \\
\text { Kredit }\end{array}$} & Lancar & $\begin{array}{c}\text { Kurang } \\
\text { Lancar }\end{array}$ & Macet & $\begin{array}{c}\text { Total } \\
\text { Tunggakan }\end{array}$ & $\begin{array}{c}\text { \% } \\
\text { Tunggakan }\end{array}$ \\
\cline { 3 - 4 } & & & & & \\
\hline $\mathbf{2 0 1 7}$ & 8.800 .365 .598 & 7.533 .992 .988 & 729.032 .904 & 474.339 .706 & 1.266 .372 .610 & 14.39 \\
\hline $\mathbf{2 0 1 8}$ & 7.971 .530 .859 & 6.942 .406 .225 & 662.434 .214 & 366.690 .419 & 1.029 .124 .634 & 12,91 \\
\hline Okt-19 & 7.758 .396 .337 & 6.329 .272 .732 & 785.925 .549 & 634.171 .056 & 1.429 .096 .605 & 18,42 \\
\hline
\end{tabular}

Sumber: KUD Karya Mukti

Berdasarkan data di tabel 1, total tungggakan atau kredit bermasalah melebihi 5\%. Hal tersebut tentunya menjadi masalah sebab ketika kita mengacu kepada peraturan Bank Indonesia Total Kredit Bermasalah tidak boleh melebihi 5\%. Namun, hal tersebut masih tetap saja terjadi padahal berdasarkan observasi awal dengan pengurus, unit simpan pinjam tersebut sudah menerapkan prinsip 5C untuk menganalisa calon nasabah sebelum memberikan keputusan kredit, tetapi penerapannya belum maksimal. Berdasarkan informasi 
yang diperoleh, total tunggakan yang selalu lebih dari 5\% ini sangat mempengaruhi laba yang didapatkan oleh unit simpan pinjam tersebut. Beberapa tahun terakhir ini laba yang diperoleh terus saja mengalami fluktuasi dan tidak stabil. Hal ini disebabkan karena kurang maksimalnya dalam proses menganalisa nasabah dengan prinsip 5C. Dengan demikian kredit yang diberikan tidak sesuai. Selain itu, juga tidak jelas apakah penerapan konsep 5C memiliki pengaruh dalam memutuskan kredit yang akan diberikan. Untuk itu peneliti tertarik untuk melakukan penelitian dengan judul "Pengaruh Konsep 5C terhadap Keputusan Pemberian Kredit pada Unit Simpan Pinjam KUD Karya Mukti di Kuamang Kuning Kabupaten Bungo”.

\section{B. TELAAH PUSTAKA}

\section{Pengertian Kredit dan Pembiayaan}

Berdasarkan Undang-Undang Nomor 10 Tahun 1998 tentang Perbankan, kredit merupakan penyediaan uang atau tagihan yang dapat dipersamakan dengan itu berdasarkan persejutuan atau kesepakatan pinjam meminjam antara bank dengan pihak lain yang mewajibkan pihak peminjam melunasi utangnya setelah jangka waktu tertentu dengan pemberian bunga. Sedangkan pengertian pembiayaan adalah penyediaan uang atau tagihan yang dapat dipersamakan dengan itu, berdasarkan persetujuan atau kesepakatan antara bank dengan pihak lain yang mewajibkan pihak yang dibiayai untuk mengembalikan uang atau tagihan tersebut setelah jangka waktu tertentu dengan imbalan atau bagi hasil.

Dapat disimpulkan bahwa kredit maupun pembiayaan merupakan uang ataupun tagihan yang nilainya diukur dengan uang. Hal tersebut misalnya saja seperti pembelian rumah atau mobil yang dibiayai oleh bank dengan adanya perjanjian antara bank (creditor) dengan nasabah (debtor). Perjanjiannya mencakup hak dan kewajiban, jangka waktu, bunga yang telah ditetapkan bersama serta mengenai sanksi apabila suatu saat terjadi ingkar janji terhadap kesepakatan yang telah dibuat bersama.

Dalam arti luas, kredit berarti kepercayaan. Begitu pula dalam bahasa latin kredit "credere" yang berarti percaya. Maksudnya, si pemberi kredit percaya kepada si penerima kredit bahwa kredit yang disalurkan pasti akan dikembalikan sesuai perjanjian. Bagi penerima kredit menerima kepercayaan sehingga mempunyai kewajiban untuk membayar sesuai dengan jangka waktu yang ditentukan. Sebelum kredit diberikan, untuk meyakinkan bahwa si nasabah benar-benar dapat dipercaya, maka terlebih dahulu mengadakan analisis kredit. Analisis kredit mencakup latar belakang nasabah atau perusahaan prospek usahanya, jaminan yang diberikan serta faktor-faktor lainnya. Tujuan 
analisis ini adalah agar bank yakin bahwa kredit yang diberikan benar-benar aman (Kasmir: 2014)

\section{Unsur-unsur Kredit}

Menurut Kasmir (2014) unsur-unsur yang terkandung dalam pemberian suatu fasilitas kredit sebagai berikut:

1. Kepercayaan

Kepercayaan merupakan keyakinan dari pemberi kredit bahwa kredit yang diberikan (berupa uang, barang atau jasa) akan dapat diterima kembali dimasa datang. Kepercayaan ini diberikan oleh bank, dengan sebelumnya sudah melakukan penelitian penyelidikan (observasi) kepada nasabah tentang kondisi masa lalu dan sekarang terhadap nasabah pemohon kredit baik secara interen maupun eksteren.

2. Kesepakatan

Unsur kesepakatan terjadi antara si pemberi kredit dengan si penerima kredit yang kemudian dituangkan dalam perjanjian yang tandatangani oleh masing-masing pihak sesuai dengan hak dan kewajibannya.

3. Jangka waktu

Setiap kredit memiliki jangka waktu yang telah ditentukan, yakni mencakup masa pengembalian kredit yang telah disepakati. Jangka waktu tersebut berbentuk jangka pendek, jangka menengah ataupun jangka panjang.

4. Risiko

Tenggang waktu pengembalian dapat menyebabkan suatu risiko tidak tertagihnya atau macetnya suatu kredit yang diberikan. Semakin panjang jangka waktu suatu kredit maka semakin besar risikonya begitu pula sebaliknya. Risiko ini akan menjadi tanggungan bagi pihak bank, baik risiko yang tidak sengaja. Misalnya, terjadi bencana alam atau bangkrutnya usaha nasabah tanpa ada unsur kesengajaan.

5. Balas jasa

Merupakan keuntungan atas pemberian suatu kredit atau jasa tersebut yang kita kenal dengan nama bunga. Balas jasa dalam bentuk bunga dan biaya administrasi kredit ini merupakan keuntungan bank. Sedangkan bagi bank yang berdasarkan prinsip syariah balas jasanya ditentukan dengan bagi hasil. 


\section{Prinsip Pemberian Kredit}

Prinsip-prinsip dalam memberikan kredit dikenal dengan Konsep 5C. Adapun penjelasan Konsep 5C menurut Kasmir (2014) adalah:

\section{Character}

Character merupakan keyakinan bahwa, sifat maupun watak dari orang-orang yang akan diberikan kredit dapat dipercaya, hal ini dapat dilihat dari latar belakang nasabah baik yakni dari segi pekerjaan maupun yang bersifat pribadi seperti cara atau gaya hidup yang dianutnya, keadaan keluarga, hobi, dan sosial standingnya. Ini semua sebagai ukuran "kemauan" membayar.

\section{Capacity}

Capacity digunakan untuk melihat nasabah dalam hal kemampuannya di bidang bisnis yang dihubungkan dengan pendidikannya, kemampuan bisnis yang diukur dengan kemampuan memahami ketentuan-ketentuan pemerintah serta kemampuannya dalam menjalankan usahanya. Maka akan terlihat "kemampuannya" dalam mengembalikan kredit yang disalurkan.

\section{Capital}

Capital digunakan untuk melihat penggunaan modal apakah efektif atau tidak, yang dilihat dari laporan keuangan (neraca dan laporan rugi laba) dengan pengukuran dari segi likuiditas, solvabilitas, rentabilitas, dan ukuran lainnya. Capital juga mengukur dari mana saja sumber modal yang ada sekarang ini.

\section{Collateral}

Collateral berupa jaminan yang diberikan oleh calon nasabah yang bersifat fisik maupun nonfisik. Jaminan yang diberikan harus melebihi jumlah kredit yang akan diterima. Jaminan yang diberikan harus diteliti keabsahannya sehingga jika terjadi suatu masalah, maka jaminan yang dititipkan akan dapat dipergunakan dengan cepat.

\section{Condition of Economy}

Dalam menilai suatu kredit juga harus menilai kondisi ekonomi dan politik sekarang serta yang akan datang sesuai dengan sektor masing-masing dan prospek usaha dari sektor yang sedang dijalankan. Penilaian prospek bidang usaha yang dibiayai hendaknya benar-benar memiliki prospek yang baik sehingga kemungkinan kredit bermasalah tersebut relatif kecil. 


\section{Prosedur dalam Pemberian Kredit}

Prosedur pemberian kredit secara umum dapat dibedakan antara pinjaman perseorangan dengan pinjaman oleh suatu badan hukum, kemudian dapat pula ditinjau dari segi tujuannya apakah untuk konsumtif ataupun produktif. Secara umum akan dijelaskan prosedur pemberian kredit oleh badan hukum sebagai berikut (Kasmir, 2014):

1. Pengajuan berkas-berkas

Dalam hal ini pemohon kredit mengajukan permohonan kredit yang dituangkan dalam suatu proposal

2. Penyelidikan berkas pinjaman

Tujuannya adalah untuk mengetahui apakah berkas yang diajukan sudah lengkap sesuai dengan persyaratan dan sudah benar.

3. Wawancara I

Merupakan penyidikan kepada calon peminjam dengan langsung berhadapan dengan calon peminjam, untuk meyakinkan apakah berkas-berkas tersebut sesuai dan lengkap seperti dengan yang diinginkan.

\section{On the Spot}

Merupakan kegiatan pemeriksaan ke lapangan dengan meninjau berbagai objek yang dijadikan usaha atau jaminan.

5. Wawancara II

Wawancara II merupakan suatu aktivitas memperbaiki berkas-berkas, jika masih terdapat kekurangan setelah dilakukan on the spot di lapangan.

6. Keputusan kredit

Keputusan kredit berarti menentukan apakah kredit tersebut diberikan atau ditolak, jika diterima, maka perlu mempersiapkan administrasinya, keputusan kredit tersebut mencakup jumlah uang yang diterima, jangka waktu kredit serta biaya-biaya yang harus dibayar.

7. Penandatanganan akad kredit / perjanjian kredit yang lain

Kegiatan ini berupa kelanjutan dari keputusan kredit, maka sebelum kredit dicairkan terlebih dahulu calon nasabah menandatangani akad kredit, mengikat jaminan dengan hipotek dan surat perjanjian atau pernyataan yang diperlukan.

8. Realisasi kredit

Realisasi kredit akan diberikan setelah penandatanganan surat-surat yang diperlukan dengan membuka rekening giro atau tabungan pada bank yang bersangkutan.

9. Penyaluran atau penarikan dana 
Penyaluran atau penarikan dana merupakan pencairan maupun pengambilan uang dari rekening sebagai realisasi dari pemberian kredit serta dapat diambil sesuai dengan ketentuan dan tujuan kredit dapat secara sekaligus atau secara bertahap.

Berdasarkan hasil penelitian terdahulu dari Maristiana. et al (2016), Wulandari (2012), dan Apriana, et al. (2017) menyimpulkan bahwa konsep 5C berpengaruh terhadap keputusan pemberian kredit. Hal ini berarti bahwa suatu lembaga keuangan baik bank maupun non bank harus melakukan analisis 5C untuk mengetahui bagaimana kemampuan nasabah dalam membayar. Penarapan analisis 5C (Character, Capacity, Capital, Collateral, Condition) dapat memberikan kesimpulan akhir apakah kredit tersebut akan diberikan atau tidak kepada nasabah. Dengan konsep 5C ini pihak kreditur atau pihak USP dapat mengkaji secara mendalam bagaimana karakter, kemampuan, keuangan, jaminan yang diberikan, dan kondisi perekonomian nasabah sehingga kredit yang diputuskan benar-benar sesuai dengan yang diharapkan.

Gambar 1. Bagan Kerangka Pemikiran

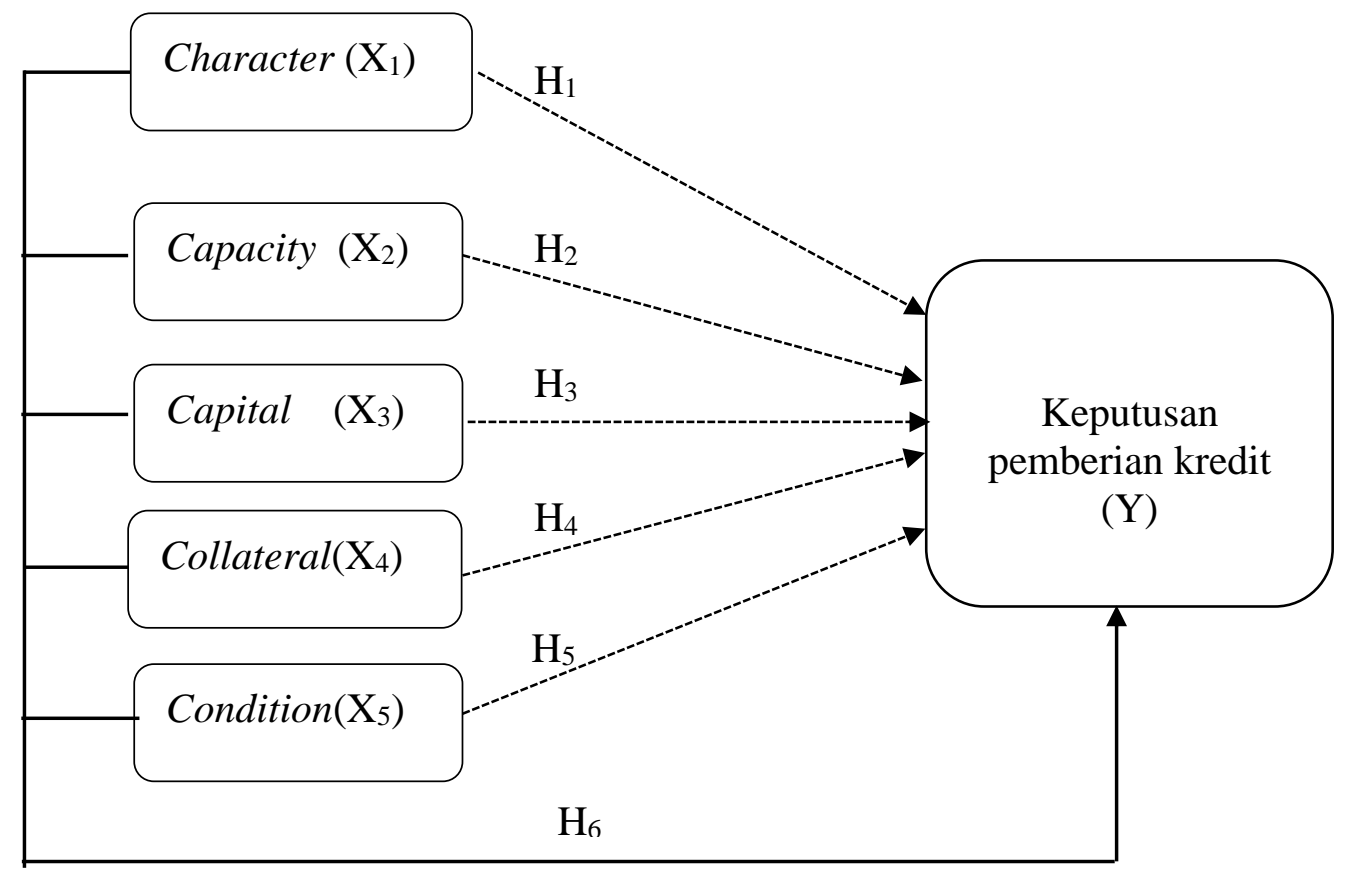

Keterangan:

$\longrightarrow=$ Pengaruh masing-masing variabel secara simultan

$\rightarrow=$ Pengaruh variabel secara parsial

Dari penelitian yang sudah dilakukan tersebut menyatakan bahwa character berpengaruh positif signifikan terhadap keputusan kredit, capacity berpengaruh positif 
signifikan tehadap keputusan kredit, capital berpengaruh positif signifikan terhadap keputusan kredit, collateral berpengaruh positif signifikan terhadapkeputusan kredit, condition of economy berpengaruh positif signifikan terhadap keputusan kredit dan secara simultan menyatakan bahwa variabel character, capacity, capital, collateral, condition of economy secara bersama-sama berpengaruh terhadap keputusan. Dengan demikian kerangka pemikiran yang dibuat peneliti ditunjukan oleh gambar 1 .

\section{METODOLOGI PENELITIAN}

\section{Metode Penelitian}

Penelitian ini menggunakan metode deskriptif dengan pendekatan kuantitatif. Penelitian digunakan untuk meneliti pada populasi atau sampel tertentu, pengumpulan data menggunakan instrumen penelitian, dan analisis data bersifat statistik (data angka) dan bertujuan untuk menguji hipotesis dengan format hubungan kausal.

1. Definisi Operasional

Operasionalisasi variabel adalah suatu kegiatan menjabarkan konsep variabel menjadi konsep yang lebih sederhana berupa indikator.Variabel penelitian merupakan karakteristik yang akan diamati (diobservasi) dari satuan pengamatan. Karakteristik adalah cara tertentu pada objek yang diteliti (diperiksa, diamati, diukur, atau dihitung), yang dapat membedakan objek tersebut dengan objek lainnya. Variabel dalam penelitian ini adalah sebagai berikut :

a. Variabel Independen

Variabel independen (bebas) adalah variabel yang mempengaruhi atau menyebabkan terjadinya perubahan pada variabel dependen (terikat). Dengan demikian dinamakan variabel bebas karena bebas dalam mempengaruhi variabel lainnya. Variabel independen dalam penelitian ini adalah konsep 5C (character, capacity, capital, collerteral, condition of economy).

b. Variabel Dependen

Variabel dependen (terikat) adalah variabel yang mempengaruhi atau yang menjadi akibat karena adanya variabel bebas.Variabel terikat dalam penelitian ini adalah kredit bermasalah. 
Operasionalisasi variabel dalam penelitian ini dapat dilihat pada Tabel 2.

Tabel 2. Definisi Operasional

\begin{tabular}{|c|c|c|c|}
\hline $\begin{array}{c}\text { Jenis } \\
\text { Variabel }\end{array}$ & Definisi & Indikator & Skala \\
\hline $\begin{array}{l}\text { Character } \\
\left(\mathrm{X}_{1}\right)\end{array}$ & $\begin{array}{l}\text { Character merupakan keyakinan } \\
\text { bahwa, sifat maupun watak dari } \\
\text { orang-orang yang akan diberikan } \\
\text { kredit dapat dipercaya, hal ini dapat } \\
\text { dilihat dari latar belakang nasabah } \\
\text { baik yakni dari segi pekerjaan } \\
\text { maupun yang bersifat pribadi seperti: } \\
\text { cara atau gaya hidup yang dianutnya, } \\
\text { keadaan keluarga, hoby dan sosial } \\
\text { standingnya. Ini semua sebagai } \\
\text { ukuran "kemauan" membayar. } \\
\text { (Kasmir, 2014) }\end{array}$ & $\begin{array}{l}\text { 1. Bank telah lama berdiri. } \\
\text { 2. Keyakinan nasabah } \\
\text { dalam keluarga yang } \\
\text { baik dan berkecukupan. } \\
\text { 3. Nasabah yang diberi } \\
\text { kredit memiliki sifat- } \\
\text { sifat yang baik. } \\
\text { 4. Nasabah memiliki } \\
\text { pergaulan yang baik } \\
\text { dalam masyarakat } \\
\text { 5. Hubungan nasabah } \\
\text { dengan relasi cukup } \\
\text { baik. Habangan } \\
\text { 6. Hubungan nasabah } \\
\text { dengan bank cukup baik. } \\
\text { 7. Kondisi tempat tinggal } \\
\text { nasabah cukup baik. } \\
\text { Maristiana. et al(2016) }\end{array}$ & $\begin{array}{l}\text { Skala } \\
\text { Likert }\end{array}$ \\
\hline $\begin{array}{l}\text { Capacity } \\
\left(\mathrm{X}_{2}\right)\end{array}$ & $\begin{array}{l}\text { Capacity Untuk melihat nasabah } \\
\text { dalam kemampuannya dalam bidang } \\
\text { bisnis yang dihubungkan dengan } \\
\text { pendidikannya, kemampuan bisnis } \\
\text { juga diukur dengan kemampuannya } \\
\text { dalam memahami tentang ketentuan- } \\
\text { ketentuan pemerintah. Begitu pula } \\
\text { dengan kemampuannya menjalankan } \\
\text { usahanya selama ini. Pada akhirnya } \\
\text { akan terlihat "kemampuannya" } \\
\text { dalam mengembalikan kredit yang } \\
\text { disalurkan. (Kasmir,2014) }\end{array}$ & 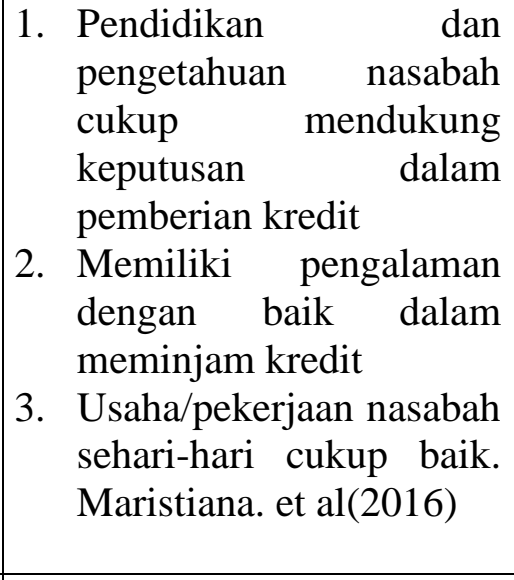 & $\begin{array}{l}\text { Skala } \\
\text { Likert }\end{array}$ \\
\hline $\begin{array}{l}\text { Capital } \\
\left(\mathrm{X}_{3}\right)\end{array}$ & $\begin{array}{l}\text { Capital digunakan untuk melihat } \\
\text { penggunaan modal apakah efektif, } \\
\text { dilihat laporan keuangan (neraca dan } \\
\text { laporan rugi laba) dengan melakukan } \\
\text { pengukuran seperti dari segi } \\
\text { likuiditas, solvabilitas, rentabilitas, } \\
\text { dan ukuran lainnya. Capital juga } \\
\text { harus dari sumber mana saja modal } \\
\text { yang ada sekarang ini. } \\
\text { (Kasmir,2014) }\end{array}$ & \begin{tabular}{|l} 
1. \\
Pertimbangan modal \\
yang dimiliki nasabah. \\
2. Kepercayaan terhadap \\
modal kredit. \\
3. Komposisi modal yang \\
diberikan nasabah \\
seimbang. \\
4. Kesangsian terhadap \\
modal. Maristiana. et \\
al(2016) \\
\end{tabular} & $\begin{array}{l}\text { Skala } \\
\text { Likert }\end{array}$ \\
\hline $\begin{array}{l}\text { Collateral } \\
\left(\mathrm{X}_{4}\right)\end{array}$ & $\begin{array}{l}\text { Collateral merupakan jaminan yang } \\
\text { diberikan calon nasabah baik yang } \\
\text { bersifat fisik maupun non fisik. }\end{array}$ & $\begin{array}{l}\text { 1. Status kepemilikan } \\
\text { agunan dominan dalam } \\
\text { pemberian kredit. }\end{array}$ & $\begin{array}{l}\text { Skala } \\
\text { Likert }\end{array}$ \\
\hline
\end{tabular}




\begin{tabular}{|c|c|c|c|}
\hline $\begin{array}{c}\text { Jenis } \\
\text { Variabel }\end{array}$ & Definisi & Indikator & Skala \\
\hline & $\begin{array}{l}\text { Jaminan hendaknya melebihi jumlah } \\
\text { kredit yang diberikan. Jaminan juga } \\
\text { harus diteliti keabsahannya sehingga } \\
\text { terjadi suatu masalah, maka jaminan } \\
\text { yang dititipkan akan dapat } \\
\text { dipergunakan secepat mungkin. } \\
\text { (Kasmir,2014) }\end{array}$ & 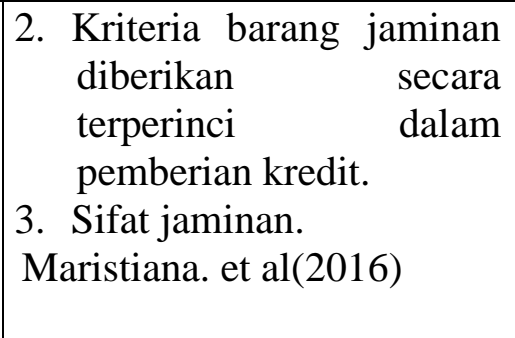 & \\
\hline $\begin{array}{l}\text { Condition } \\
\text { of } \\
\text { economy } \\
\left(\mathrm{X}_{5}\right)\end{array}$ & $\begin{array}{l}\text { Condition digunakan untuk menilai } \\
\text { kondisi ekonomi dan politik } \\
\text { sekarang serta masa yang akan } \\
\text { datang sesuai sektor masing-masing } \\
\text { dan prospek usaha dari sektor yang } \\
\text { dijalankan. Penilaian prospek bidang } \\
\text { usaha yang dibiayai hendaknya } \\
\text { benar-benar memiliki prospek yang } \\
\text { baik sehingga kemungkinan kredit } \\
\text { bermasalah tersebut relatif kecil. } \\
\text { (Kasmir,2014) }\end{array}$ & 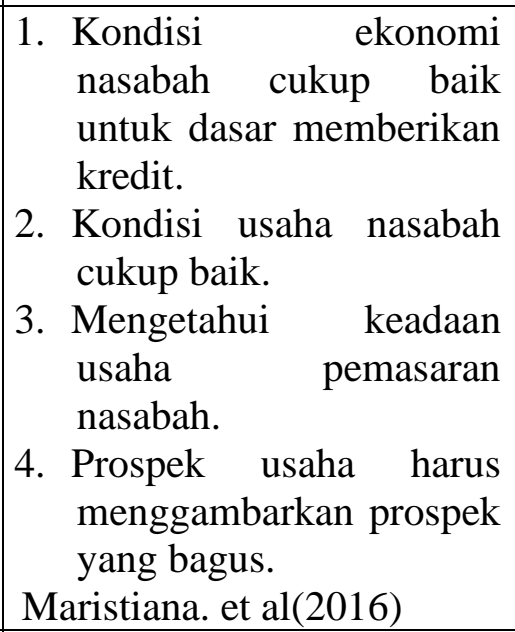 & $\begin{array}{l}\text { Skala } \\
\text { Likert }\end{array}$ \\
\hline $\begin{array}{l}\text { Keputusan } \\
\text { Pemberian } \\
\text { Kredit (Y) }\end{array}$ & $\begin{array}{l}\text { Keputusan kredit dalam hal ini } \\
\text { adalah menentukan apakah kredit } \\
\text { akan diberikan atau ditolak, jika } \\
\text { diterima, maka dipersiapkan } \\
\text { administrasinya, biasanya keputusan } \\
\text { pemberian kredit yang akan } \\
\text { mencakup jumlah uang yang } \\
\text { diterima, jangka waktu kredit, dan } \\
\text { biaya-biaya yang harus dibayar. } \\
\text { Apabila kredit ditolak, maka } \\
\text { hendaknya dikirim surat penolakan } \\
\text { sesuai dengan alasannya masing- } \\
\text { masing. (Kasmir,2014) }\end{array}$ & $\begin{array}{l}\text { 1. Informasi yang lengkap } \\
\text { memberikan kontribusi } \\
\text { besar diterimanya kredit. } \\
\text { 2. Pemilihan alternatif } \\
\text { jumlah kredit yang } \\
\text { disetujui beragam. } \\
\text { 3. Dalam keputusan } \\
\text { memberikan kredit } \\
\text { jumlahnya sesuai. } \\
\text { 4. Persepsi melihat Kinerja } \\
\text { perusahaan sangat } \\
\text { berkontribusi dalam } \\
\text { keputusan memberikan } \\
\text { kredit. } \\
\text { 5. Informasi yang tersedia } \\
\text { untuk nasabah pada saat } \\
\text { memberikan kredit, } \\
\text { tersedia dengan lengkap. } \\
\text { Maristiana. et al(2016) }\end{array}$ & $\begin{array}{l}\text { Skala } \\
\text { Likert }\end{array}$ \\
\hline
\end{tabular}


2. Populasi dan Sampel

Populasi dalam penelitian ini adalah seluruh anggota KUD Karya Mukti yang berjumlah 1522 anggota. Yang dijadikan sampel di penelitian ini adalah anggota koperasi yang belum pernah ataupun yang sudah pernah melakukan pinjaman dan juga anggota yang masih berstatus sebagai nasabah. Pengambilan sampel ditetapkan harus dari anggota koperasi sebab dalam melakukan pinjaman di unit simpan pinjam tersebut hanya anggotalah yang dapat melakukan pinjaman. Dikarenakan populasi atau jumlah anggota sangat banyak maka untuk penentuan jumlah sampel diambil dengan menggunakan rumus slovin dengan tingkat signifikan 10\% maka sampel yang diambil adalah 94 orang dari anggota koperasi. Teknik pengambilan sampel yang digunakan adalah simple random sampling.

3. Teknik Analisis Data

Teknik analisis data dapat diartikan sebagai cara melaksanakan analisis terhadap data, dengan tujuan mengolah data tersebut menjadi informasi, sehingga karakteristik atau sifatsifat datanya dapat dengan mudah dipahami dan bermanfaat untuk menjawab masalahmasalah yang berkaitan dengan kegiatan penelitian. Pengolahan data yang dilakukan dalam penelitian ini ialah dengan uji analisis linear berganda dengan menggunakan bantuan progam SPSS (Statictical Package for Sosial Science) versi 20.

\section{HASIL DAN PEMBAHASAN}

\section{Hasil Uji Analisis Regresi Linier Berganda}

Tabel 3. Hasil Analisis Regresi Berganda

Coefficients $^{\mathrm{a}}$

\begin{tabular}{|c|c|c|c|c|c|c|}
\hline & \multirow[t]{2}{*}{ Model } & \multicolumn{2}{|c|}{$\begin{array}{c}\text { Unstandardized } \\
\text { Coefficients }\end{array}$} & \multirow{2}{*}{$\begin{array}{c}\text { Standardized } \\
\text { Coefficients } \\
\text { Beta } \\
\end{array}$} & \multirow[t]{2}{*}{$\mathbf{T}$} & \multirow[t]{2}{*}{ Sig. } \\
\hline & & B & Std. Error & & & \\
\hline \multirow{6}{*}{1} & (Constant) & 10,644 & 2,125 & & 5,010 &, 000 \\
\hline & $\mathrm{X} 1$ & ,109 & ,066 & , 162 & 1,674 &, 006 \\
\hline & $\mathrm{X} 2$ & ,052 & , 101 &, 052 &, 516 & 607 \\
\hline & $\mathrm{X} 3$ &, 044 & , 100 & ,049 & ,438 & ,662 \\
\hline & $\mathrm{X} 4$ &, 247 & , 128 & ,235 & 1,930 & ,057 \\
\hline & $\mathrm{X} 5$ & ,221 &, 088 & ,281 & 2,512 &, 014 \\
\hline
\end{tabular}

a. Dependent Variable: Y

Sumber : Data diolah, 2020

Regresi linier berganda digunakan untuk mengetahui pengaruh antara dua variabel atau lebih dari variabel bebas (independen) terhadap satu variabel terikat (dependen). Dalam 
penelitian ini regresi linier berganda digunakan untuk mengukur pengaruh variabel character, capacity, capital, collateral, dan condition of economy terhadap keputusan pemberian kredit. Adapun hasil pengujian dapat dilihat pada Tabel 3.

Berdasarkan hasil uji analisis SPSS di atas dapat diperoleh persamaan $\mathrm{Y}=10,644+0,109 \mathrm{X}_{1}+0,052 \mathrm{X}_{2}+0,044 \mathrm{X}_{3}+0,247 \mathrm{X}_{4}+0,221 \mathrm{X}_{5}$, maka dapat diinterpretasikan nilai koefisien $\mathrm{X}_{1}$ sebesar $+0,109$ artinya setiap penambahan 1 unit nilai $\mathrm{X}_{1}$ maka akan menambah nilai $Y$ sebesar $0,109 . X_{2}$ sebesar $+0,052$ artinya setiap penambahan 1 unit nilai $\mathrm{X}_{2}$ maka akan menambah nilai $\mathrm{Y}$ sebesar 0,052. $\mathrm{X}_{3}$ sebesar $+0,044$ artinya setiap penambahan 1 unit nilai X3 maka akan menambah nilai Y sebesar 0,044. $\mathrm{X}_{4}$ sebesar $+0,247$ artinya setiap penambahan 1 unit nilai $\mathrm{X}_{4}$ maka akan menambah nilai $\mathrm{Y}$ sebesar 0,247 . $\mathrm{X}_{5}$ sebesar + 0,221 artinya setiap penambahan 1 unit nilai $\mathrm{X}_{5}$ maka akan menambah nilai $\mathrm{Y}$ sebesar 0,221. Nilai-nilai tersebut bernilai positif artinya bahwa semakin tinggi dan baik character,capacity,capital,collateral, dan condition of economy nasabah maka akan semakin tinggi dan baik pula keputusan kredit yang diberikan. Nilai konstanta sebesar 10,664 yang berarti jika X1, X2, X3, X4 dan X5 = 0 maka Y = 10,664. Artinya tidak terdapat pengaruh dari variabel bebas seperti character,capacity,capital,collateral dan condition of economy.

\section{Hasil Uji Hipotesis}

1. Uji F (Simultan)

Tabel 4. Hasil Uji F (Simultan)

\begin{tabular}{|l|l|r|r|r|r|r|}
\hline \multicolumn{2}{|c|}{ Model } & $\begin{array}{c}\text { Sum of } \\
\text { Squares }\end{array}$ & \multicolumn{1}{c|}{ Df } & $\begin{array}{c}\text { Mean } \\
\text { Square }\end{array}$ & \multicolumn{1}{c|}{ F } & Sig. \\
\hline \multirow{3}{*}{1} & Regression & 142,081 & 5 & 28,416 & 8,252 &, $000^{\mathrm{b}}$ \\
\cline { 2 - 8 } & Residual & 303,025 & 88 & 3,443 & & \\
\cline { 2 - 8 } & Total & 445,106 & 93 & & & \\
\hline
\end{tabular}

a. Dependent Variable: Y

b. Predictors: (Constant), X5, X1, X3, X2, X4

Sumber : Data diolah, 2020

Berdasarkan tabel diatas dapat dilihat bahwa nilai f-hitung 8,252 $\geq$ f-tabel 1,913 dan nilai signifikan $0,000 \leq 0,1$, maka dapat disimpulkan bahwa variabel konsep 5C (character, capacity,capital, collateral, condition of economy) berpengaruh signifikan terhadap keputusan pemberian kredit $(\mathrm{Y})$ dan hipotesis enam $\left(\mathrm{H}_{6}\right)$ diterima.

2. Uji T (Parsial)

Nilai dari T-tabel pada tabel distribusi $\mathrm{T}$ untuk tingkat signifikan 0,1 adalah 1,662. Hasil uji T dapat dilihat pada Tabel 5. 
Tabel 5. Tabel Hasil hipotesis

Coefficients $^{\mathrm{a}}$

\begin{tabular}{|l|l|r|r|r|r|r|}
\hline \multirow{2}{*}{ Model } & \multicolumn{2}{|c|}{$\begin{array}{c}\text { Unstandardized } \\
\text { Coefficients }\end{array}$} & $\begin{array}{c}\text { Standardized } \\
\text { Coefficients } \\
\text { Beta }\end{array}$ & \multicolumn{1}{c|}{ T } & \multicolumn{1}{c|}{ Sig. } \\
\cline { 3 - 6 } & \multicolumn{1}{|c|}{ B } & Std. Error & & \\
\hline \multirow{2}{*}{1} & (Constant) & 10,644 & 2,125 & & 5,010 &, 000 \\
& X1 &, 109 &, 066 &, 162 & 1,674 &, 006 \\
& X2 &, 052 &, 101 &, 052 &, 516 &, 607 \\
& X3 &, 044 &, 100 &, 049 &, 438 &, 662 \\
& X4 &, 247 &, 128 &, 235 & 1,930 &, 057 \\
& X5 &, 221 &, 088 &, 281 & 2,512 &, 014 \\
\hline
\end{tabular}

a. Dependent Variable: Y

Sumber : Data diolah,2020

a. Pengujian hipotesis pertama $\left(\mathrm{H}_{1}\right)$

Berdasarkan tabel diatas diketahui bahwa nilai t-hitung 1,674 > t-tabel 1,662 dan nilai sig $0,006<0,1$. Maka dapat disimpulkan bahwa variabel character $\left(\mathrm{X}_{1}\right)$ berpengaruh signifikan terhadap keputusan pemberian kredit $(\mathrm{Y})$ dan hipotesis pertama $\left(\mathrm{H}_{1}\right)$ diterima. Hal ini memiliki arti bahwa semakin tinggi character yang dimiliki anggota maka akan semakin baik bagi pihak koperasi dalam memutuskan pemberian kredit kepada anggota.

b. Pengujian hipotesis kedua $\left(\mathrm{H}_{2}\right)$

Berdasarkan tabel di atas diketahui bahwa nilai t-hitung 0,516 < t-tabel 1,662 dan nilai sig 0,607 > 0,1. Maka dapat disimpulkan bahwa variabel capacity (X2) tidak berpengaruh terhadap keputusan pemberian kredit $(\mathrm{Y})$ dan hipotesis kedua $\left(\mathrm{H}_{2}\right)$ ditolak. Capacity dilihat atau dinilai dari pendidikan dan pengetahuan nasabah (anggota), pengalaman kredit nasabah (anggota), serta usaha/pekerjaan sehari-hari nasabah (anggota).

c. Pengujian hipotesis ketiga $\left(\mathrm{H}_{3}\right)$

Berdasarkan tabel di atas diketahui bahwa nilai t-hitung 0,438< t-tabel 1,662 dan nilai sig 0,662>0,1. Dapat disimpulkan bahwa variabel capital $\left(\mathrm{X}_{3}\right)$ tidak berpengaruh terhadap keputusan pemberian kredit $(\mathrm{Y})$ dan hipotesis ketiga $\left(\mathrm{H}_{3}\right)$ ditolak. Hal ini berarti bahwa mempertimbangkan modal yang akan diberikan, mempercayakan modal yang akan diberikan, komposisi modal, dan kesangsian terhadap modal tidak berpengaruh terhadap keputusan pemberian kredit atau menjadi pertimbangan dalam memutuskan diterimanya kredit atau tidak. Capital tidak berpengaruh terhadap keputusan pemberian kredit dapat disebabkan karena pihak koperasi memegang unsur kepercayaan yang menjadi salah satu unsur dalam 
pemberian kredit terhadap anggotanya bahwa tanpa melihat modal yang diberikan mereka yakin bahwa anggotanya dapat membayar.

d. Pengujian hipotesis keempat $\left(\mathrm{H}_{4}\right)$

Berdasarkan tabel di atas diketahui bahwa nilai t-hitung 1,930>t-tabel 1,662 dan nilai sig $0,057<0,1$. Dapat disimpulkan bahwa variabel collateral (X4) berpengaruh signifikan terhadap keputusan pemberian kredit $(\mathrm{Y})$ dan hipotesis keempat $\left(\mathrm{H}_{4}\right)$ diterima. Dalam hal ini berarti bahwa semakin jelas pihak koperasi menganalisa jaminan kredit yang diberikan nasabah (anggota) maka risiko tak tertagihnya hutang menjadi rendah dan keputusan dalam memberikan kredit semakin baik. Maka dalam memberikan kredit pihak kreditur (koperasi) harus sangat memperhatikan dengan teliti status kepemilikan agunan, bagaimana kriteria barang jaminan dan bagaimana jaminan yang akan diberikan oleh calon debitur. Ketika semua sudah sesuai dengan syarat-syarat jaminan yang ditetapkan pihak debitur barulah keputusan kredit dapat diberikan.

e. Pengujian hipotesis kelima $\left(\mathrm{H}_{5}\right)$

Berdasarkan tabel diatas diketahui bahwa nilai t-hitung 2,512>t-tabel 1,662 dan nilai sig $0,014<0,1$. Dapat disimpulkan bahwa variabel condition of economy $\left(\mathrm{X}_{5}\right)$ berpengaruh signifikan terhadap keputusan pemberian kredit (Y) dan hipotesis kelima $\left(\mathrm{H}_{5}\right)$ diterima. Dalam hal ini berarti kondisi ekonomi nasabah sangat mempengaruhi keputusan debitur (koperasi) dalam memberikan kreditnya dan semakin baik kondisi ekonomi nasabah (anggota) maka kemungkinan diterimanya kredit semakin besar. Hal ini sesuai dengan ekonomi kreditur apabila kondisi ekonomi kreditur atau nasabah stabil atau baik, kondisi usahanya lancar, keadaan usaha pemasarannya berkembang baik serta kemajuan atau prospek usahanya baik maka pihak debitur (koperasi) kemungkinan besar akan memberikan kreditnya. Sedangkan ketika kondisi ekonomi yang tiba-tiba turun pada saat kredit sudah diterima maka tak tertagihnya hutang kemungkinan terjadi. Hal tersebutlah yang menyatakan dan sesuai dengan hasil uji bahwa variabel condition of economy memiliki pengaruh paling tinggi dibanding variabel konsep 5C terhadap keputusan pemberian kredit.

\section{Koefisien Determinasi $\left(\mathbf{R}^{2}\right)$}

Pengujian koefisien determinasi bertujuan untuk mengetahui besar kontribusi variabel bebas (independen) terhadap variabel terikat (dependen). Berdasarkan tabel 6 dapat diketahui bahwa 0,585 x $100=58,5 \%$ yang berarti bahwa besar kontribusi variabel 
independen $\left(\mathrm{X}_{1}, \mathrm{X}_{2}, \mathrm{X}_{3}, \mathrm{X}_{4}, \mathrm{X}_{5}\right)$ dalam mempengaruhi variabel dependen (Y) sebesar 58,5\% selebihnya di pengaruhi oleh variabel-variabel lain diluar penelitian.

Tabel 6. Hasil Uji Koefisien Determinasi $\left(\mathrm{R}^{2}\right)$

Model Summary ${ }^{\mathrm{b}}$

\begin{tabular}{|l|l|r|r|c|}
\hline Model & $\mathbf{R}$ & R Square & $\begin{array}{c}\text { Adjusted R } \\
\text { Square }\end{array}$ & $\begin{array}{c}\text { Std. Error of the } \\
\text { Estimate }\end{array}$ \\
\hline 1 &, $765^{\mathrm{a}}$ &, 585 &, 281 & 1,856 \\
\hline
\end{tabular}

a. Predictors: (Constant), X5, X1, X3, X2, X4

b. Dependent Variable: Y

Sumber: Data diolah, 2020

\section{E. KESIMPULAN}

Berdasarkan hasil uji analisis regresi linear berganda didapatkan $Y=10,644+0,109 X_{1}$ $+0,052 X_{2}+0,044 X_{3}+0,247 X_{4}+0,221 X_{5}$, yang berarti apabila variabel $X_{1}, X_{2}, X_{3}, X_{4}, X_{5}=0$ maka $\mathrm{Y}=10,644$. Berdasarkan hasil uji tersebut masing-masing variabel character, capacity, capital, collateral, dan condition of economy menunjukkan penambahan nilai yang positif terhadap variabel keputusan pemberian kredit yang artinya semakin tinggi masing-masing variabel $\mathrm{X}$ tersebut maka semakin baik keputusan dalam memberikan kredit.

Hasil uji secara simultan disimpulkan bahwa variabel konsep 5C (character, capacity, capital, collateral dan condition of economy) berpengaruh positif signifikan terhadap keputusan pemberian kredit. Pengujian ini sesuai dan sejalan dengan hasil penelitian yang telah dilakukan sebelumnya yaitu penelitian yang digunakan sebagai rujukan yakni dari Maristiana. et al (2016), Wulandari (2012), Apriana, et al (2017), dan Oka, et al (2015).

Hasil uji secara parsial menunjukkan hasil bahwa variabel character berpengaruh positif signifikan terhadap keputusan pemberian kredit, variabel capacity tidak berpengaruh terhadap keputusan pemberian kredit, variabel capital tidak berpengaruh terhadap keputusan pemberian kredit. Variabel collateral berpengaruh positif signifikan terhadap keputusan pemberian kredit, serta variabel condition of economy berpengaruh positif signifikan terhadap keputusan pemberian kredit. Hasil uji ini memberikan kesimpulan bahwa dalam penelitian ini variabel yang secara langsung mempengaruhi keputusan kredit adalah variabel character, collateral, dan condition of economy.

Berdasarkan hasil uji koefisien determinasi menunjukan bahwa variabel konsep 5C memberikan kontribusi pengaruh terhadap keputusan pemberian kredit sebesar 58,5\% selebihnya dipengaruhi oleh variabel lain diluar penelitian. 


\section{Saran}

Bagi pengurus koperasi, berdasakan hasil uji terbukti bahwa konsep 5 memberikan kontribusi pengaruh sebesar 58,5\% terhadap keputusan pemberian kredit, maka hendaknya penerapan konsep 5C diterapkan dengan maksimal karena penerapan konsep 5C tersebut bertujuan untuk menghindari tak tertagihnya hutang. Variabel yang terbukti berpengaruh dalam menentukan keputusan pemberian kredit adalah variabel character (karakter), collateral (jaminan), dan condition of economy (kondisi ekonomi), maka hendaknya dijadikan sebagai pertimbangan utama dalam memutuskan diterimanya kredit atau tidak, namun capacity (kemampuan) dan capital (modal) juga harus tetap diperhatikan dalam menganalisa calon nasabah (anggota) sebelum memutuskan diterimanya kredit atau tidak.

Bagi anggota koperasi, diharapkan mampu bekerjasama dengan pengurus untuk menerapkan konsep 5C ini lebih baik lagi dan secara maksimal agar Unit Simpan Pinjam pada Koperasi Unit Desa Karya Mukti terhindar dari kredit bermasalah, selain itu hendaknya anggota koperasi harus mampu memegang komitmen untuk tidak menunggak, karena hal ini akan mempengaruhi pihak koperasi untuk memutuskan memberikan kreditnya atau tidak. Bagi peneliti selanjutnya diharapkan dapat menambahkan variabel lain seperti prinsip 7P (personality, party, purpose, prospect, payment, dan protection) ataupun karakteristik usaha, karakteristik kredit, dan lain-lain.

\section{DAFTAR PUSTAKA}

Apriana, S., Artiningsih, D.W., \& Irwansyah (2017). Analisis Pengaruh Prasyarat Kredit (5C) Terhadap Kelancaran Pembayaran Angsuran Nasabah di Bank Kalsel Unit Sentra Antasari Banjarmasin. Jurnal Bisnis dan Pembangunan,6(1).

Ikatan Bankir Indonesia. (2015). Bisnis Kredit Perbankan. Jakarta Pusat: Gramedia Pusaka Utama.

Kasmir. (2014). Bank Dan Lembaga Keuangan Lainnya edisi revisi 2014. Jakarta: Rajawali Pers.

Maristiana, S., Hartono, \& Supriyanto, A. (2016). Pengaruh Analisis 5C (Character, Capacity, Capital, Collateral and Condition) Dalam pemberian kredit di Bank BRI Unit Indraprasta, Jurnal Akuntansi, 5(10)

Oka, K.W. L., Purnamawati, I.G.A., \& Sinarwati, N.K. (2015). Pengaruh Dana Pihak Ketiga, Penilaian 5C Kredit dan Kualitas Kredit Terhadap Keputusan Pemberian Kredit di PT Bank Pembangunan Daerah Bali Cabang Singaraja. E-jurnal SI Ak Universitas Pendidikan Ganesa, 3(1). 10-18

Wulandari, D.A.D. (2012). Pengaruh Five "C"s of Credit Terhadap Proses Pemberian Kredit pada BPR di Kota Semarang. Jurnal Ilmu Administrasi Bisnis, 3(37). 212-225. 